\author{
Sylwia Leszczuk \\ - University of Bialystok \\ - e-mail: s.leszczuk@uwb.edu.pl \\ - ORCID: 0000-0002-0897-3136
}

\title{
THE END OF THE CLASSICAL PARADIGMS OF LAW
}

\section{Abstract}

- Goal - the aim of this text is to show the functioning, transformation, convergence and ultimately decline of classical paradigms operating in the legal sphere. Particular attention is focused on the contemporary state of affairs, referring to today's trends in thought, philosophy and the contemporary way of explaining reality by societies that are carriers of the law. The purpose is to showcase that the today's changing world is faced with many problems that are completely new to humanity as a whole, and that those problems have the power to affect the legal sphere as well. It proves that despite the belief in the stabilizing function of the law, it itself begins to be questioned, and its iron foundations begin to waver in principle, resulting in spectacular changes in the way we view such non-negotiable issues as justice, power, order, and the meaning of being.

- Research methodology - through an analysis of the literature on the subject and by compiling the most important paradigmatic frameworks, a cross-section of attitudes relevant to understanding the presented issue is made.

- Score/result - as a result, an observation is made regarding the current state of paradigms operating in the legal sphere. In line with the conclusion, it is stated that in the present world paradigms have mostly lost or are losing their power. They will lose it completely or undergo a transformation. There is also an exhaustion of the power of all grand narratives that must necessarily be taken into account when making any considerations about the embeddedness of law and its validity.

- Originality/value - the content of the text refers to well-known paradigms of law that seem to be unshakable elements of Western legal culture. Nevertheless, the analysis of the problems presented in the text shows that the unshakable foundations 
of law are beginning to degrade, or at least to change, in collision with, above all, contemporary socio-cultural transformations.

| Keywords: paradigm, legal science paradigms, legal science, philosophy of law, grand narratives, disenchantment of the world.

\section{Introduction}

The times we live in are often referred to as the "end of history", whether in the way Francis Fukuyama, a proponent of the idea of the triumph of liberal democracy and free market over any other system, understands it or leaning towards a slightly more negative thought - the claim that man has exhausted the ability to harmonize and rationalize reality and the only thing that can still await humanity is the chaos of information and stimuli overload or the deconstruction of all the achievements of social development, comparable to the Big Collapse theory, except that in relation to the decomposition of Western civilization.

Whichever assumption one makes, however, one has to agree with the statement that today's world is in the throes of many transformations. In view of this, it should also be assumed that this state of affairs applies to all spheres of human activity and life, as well as to social structures. And this in turn leads to a simple statement that transformations are also taking place in law, which after all derives its existence from the existence of society.

This text aims to analyse the statement that currently we are dealing with a situation where the classical paradigms of law have faced their own end, losing the power of their own legitimacy and raison d'être. This view is particularly raised by thinkers of the postmodern era. For a better understanding of further considerations, it is necessary to look at the background of the meaning of this text. For this purpose, it is worth considering what postmodernism, as understood by the subject of this work, actually is.

Magdalena Cuprjak correctly points out that postmodern reality is a situation of permanent change [Cuprjak, 2016: 252]. Postmodernism is also characterized by a sceptical attitude to the assumption that science is capable of formulating universal truths [Skuczyński, 2014: 143]. On the other hand, the main target of attacks on the part of postmodernists is the Enlightenment myth; postmodernists want to provide an alternative to the Enlightenment knowledge, at the same time proclaiming a warning against totalitarianisms, which 
appeared after all as a result of striving to base all duty on reason, necessity, utilitarianism, science and technology.

Marek Zikr-Sadowski, on the other hand, points out that "according to postmodernists, in the history of mankind no definitive philosophical answers have been obtained in any field, and only the pursuit of philosophical searches can be considered truly significant" [Zirk-Sadowski, 2000: 132].

With the attitude of postmodernists thus depicted, the topic of this paper takes on a fuller meaning. In order to explore it more fully, however, further considerations will be necessary, the ultimate goal of which will be to determine what the title "end of classical paradigms of law" really means.

\section{What is a paradigm?}

In order to understand the considerations I have made, it will be necessary to specify what the paradigm contained in the title actually is and how it relates to law.

The word "paradigm" comes from Greek and means, among others: example, pattern, model, scheme [Walczak, 2015, 72]. Originally, the phrase referred to a Platonic idea, defining the prototype of changeable things, a certain idea or form. In modern times, for example in the field of rhetoric, it has taken on the meaning of "an exceptionally clear and typical example illustrating the discussed issue" [Kępa, 2015: 361].

The concept of paradigm in the sense more akin to the present discussion was first used in the eighteenth century by Georg Christoph Lichtenberg, who defined it as "certain fundamental patterns of explanation [...] on which networks of explanation are structured" [Walczak, 2015: 72].

A specific paradigm theory, however, was formulated and described in 1963 in The Structure of Scientific Revolutions by Thomas Kuhn, an American philosopher of science [Walczak, 2015: 68]. The thesis contained in the work states that science takes place, follows and is based on a certain pattern, considered correct or leading at a given time. The definition of paradigm proposed by the scientist was as follows: "universally recognized scientific achievements that at a certain time provide the community of scholars with model problems and solutions" [Khun, 2001: 20].

Thus, it can be assumed that a paradigm is a theory or a set of scientific theories, which, defined and approved by scholars, operate in a given place and 
time, among others, indicatingthe problems, and thus setting research objectives, driving the research process [Kepa, 2015: 362].

A paradigm is therefore a certain set of beliefs, a certain perspective, certain rules of conduct, a certain framework, a certain set of epistemological assumptions taken for granted by researchers in order to reject the need to build each time anew the field within which they conduct research, allowing the justification of the derived concepts [Cuprjak, 2016: 252-254].

According to Thomas Kuhn paradigms may undergo transformations or become completely outdated, which is the natural course of development of knowledge and science. Kuhn indicates that at some point, as a result of research and the resulting evolution of a given field, there comes a moment of crisis or revolution, "when normal science, i.e. the science practiced within the currently valid paradigm, is not able to answer the existing problems and doubts" [Walczak, 2015: 72]. Most often the state of crisis is resolved by the development of a new paradigm, which manages to fill the gaps left by the predecessor. Then again comes the moment of doubt in the new paradigm, as a result of which the process of searching for a new framework of translation begins again.

According to Karl Popper, in the social sciences, unlike in the nat u ral sciences, there is noparadigm that has become completely obsolete; the social sciences are characterized by the coexistence of several paradigms at the same time and the incidental complementarity of some of them, and it is possible to point to the so-called residuality, i.e., the incorporation of certain elements of a given paradigm into the next one as part of the changes caused by their evolution. Mateusz Kępa, echoing the assumptions made by Kuhn, points out that "for a paradigm to emerge, a complication or crisis must occur" [Kępa, 2015: 363]. As one can see, this is practically a direct reference to the thesis of the American philosopher, who describes a crisis as a necessary condition for the emergence of a new paradigm [Khun, 2001: 12]. The relevance of the crisis derives from the fact that it shows the deficiencies and lack of translation of previous views in relation to the changing reality and the currently existing situation. Consequently, the paradigm shift brought about by the crisis requires a transformation of the meanings and practices that have so far been established by the paradigm currently being overthrown. A necessary condition that must be fulfilled by the emerging paradigm is to take into account the new phenomena and discoveries that led to the undermining of its predecessor. Kępa aptly points out that "a paradigm has alwaysbeen associated with a specific method of explaining and organizing the perception of reality" [Kępa, 2015: 369]. According 
to Magdalena Cuprjak, a revolution that aims to transform a hitherto existing paradigm or to emerge a new one "consists in breaking a specific paradigmatic structure and formulating a new set of principles" [Cuprjak, 2016: 253].

Having presented the definition of a paradigm, one may proceed to point out the relevance of its existence for law. In view of the law, a paradigm is precisely a set of certain theses, assumptions, beliefs, patterns, techniques and ideas that formulate concrete legal theories and attitudes, helping to order the assumptions of the law, depending on a given paradigm. Also in accordance with the above-mentioned statements, it should be agreed that paradigms relating to law have also been subject to evolution, crises and convergences, which can be illustrated by looking at their concrete examples.

\section{Classic paradigms of law}

One of the first paradigms relating to law to be discussed is the theological paradigm, which assumes that law derives from an omnipotent, transcendent being, and that legal and religious norms are in fact identical, or at least closely related. Law is thus, in the terms of this paradigm, inextricably intertwined with religious rules and is in fact the will of God. This view, dominant until the late Renaissance, derives from the teachings of St. Augustine and St. Thomas Aquinas. The theological paradigm was gradually transformed and eventually gave way to, among other things, a legal-natural paradigm [Walczak, 2015: 74].

The legal-natural paradigm was formed in the 16th century. It draws attention to man's natural rights, belonging to him by virtue of the very fact of his being a human being, characterized by their unquestionability, immutability, and universality.

In the era when this paradigm prevailed, it was believed that there were identical laws that applied throughout the world, regardless of the state, and that these laws were superior to any law, and the source of their legitimacy is to be found in the nature of man himself, in human reason, in society, and in the nature of all things. According to Grotius, the law based on the legal-natural paradigm had four basic principles: the duty to honor one's contracts, the duty to make amends, the duty to punish criminals, and the duty not to violate the property of another, which was successively enr iched by the claims of Hobbes and Rousseau, who combined the law of nature with the idea of the social contract as the basis of all rights [Walczak, 2015: 74-75]. 
The law-of-nature paradigm lost its dominant character in the early nineteenth century, coming under the criticism of the developing legal positivism. The concept of law of nature will, however, be revisited by such thinkers as John Rawls and Gustav Radbruch, and will also appear in the provisions of the 1948 UN Universal Declaration of Human Rights and the 1950 European Convention on Human Rights.

As mentioned above, the positivist paradigm triumphed in the $19^{\text {th }}$ century, where only objective, precise, measured, and quantifiable facts were considered scientific at the time, which is attributed to the natural sciences rather than the humanities. Central to the tenets of positivism was the treatment of man not in terms of an individual, independent entity, but "a certain abstraction in the real and actual social world" [Cuprjak, 2016: 257-258]. The most important theses of positivism relating to law include the assumptions that:

- law is a set of general norms secured by a form of coercion,

- the law is created by unilateral and authoritative decisions,

- legal texts are the source of law,

- law is a system independent of morality and other normative systems,

- the law must be obeyed, even if it is wrong,

- the lawyer's task is the exegesis of legal texts [Morawski, 1999: 15-16].

John Austin's legal positivism further assumed that law was a command from the sovereign and as such should be obeyed without question. This in turn resulted in the exclusion of any morality from positivist state law [Zirk-Sadowski, 2000: 138].

At this point, having marked the basic frames of the positivistic paradigm, one should quote the words of Lech Morawski, who indicates, that the crisis of the positivistic concept of law, despite its continuous popularity, has been discussed for years. There are resounding statements about the fact that "the conception of law defended by positivism is less and less adequate to the needs of contemporary societies" [Morawski, 1999: 16]. First of all, statements are raised that the conception of law championed by positivism has proved to be completely ineffective when confronted with contemporary needs and is unable to cope with current problems. It has also been noted that positivism pays little attention to the role of law as a tool that shapes social structures. Morawski explicitly states that "the rationalization of contemporary law can or, correspondingly, cannot be done within the positivist paradigm" [Morawski, 1999: 18]. 
As it seems, a natural consequence of the popularity of positivism was the emergence of movements that were both related and critical, but also reformist. Modernism should be counted among the latter.

Modernism, the dominant worldview of industrial societies, is in short all trends and currents of thought derived from the tradition of the Enlightenment, in fact reproducing the Enlightenment systems of values. Characteristic of modernism were the convictions that science and technology are the basis for the rationalization of social relations (the so-called scientism), as well as the rules accepted in natural and empirical sciences, which were given a universal character; no less important were also such features as secularization of thinking, individualism, the belief in the rationalizing power of reason, and reliance on scientific and technological development [Morawski, 1999: 20]. In relation to law, modernism assumes that based on the Weberian model of bureaucratic organization, it is an effective instrument for controlling social processes.

The 1960s bring a crisis of modernist thought, with scholars turning away from the ideas of scientism and methodological naturalism, no longer seeing reason and developments in technology as reliable instruments and bases for rationalization, thus creating postmodernism.

Postmodernism is characterized by a multitude of internal currents of thought, for which, as Lech Morawski mentions, it is ultimately difficult to find a common denominator, apart from a common rejection of the assumptions of positivism and its modernist reform. The framework of postmodernism includes, among others:

- Critical Legal Studies,

- the literary school of law (Law and Literature),

- feminist law school,

- ethnic theory of law,

- economic school of law (Law and Economics) [Morawski, 1999: 22].

Lech Morawiecki points out that "in the conviction of postmodernists, the concept of law based on the positivist paradigm has become an anachronism and is not able to face the problems of societies at the end of the $20^{\text {th }}$ century. In fact, today it serves as an instrument for preserving the social, economic and political status quo" [Morawski, 1999: 23].

Modernists and postmodernists agree that since the second half of the twentieth century positivist ideas about law have become anachronistic and are unable to defend themselves in the face of the social changes of the modern 
world. However, modernists believe that there is a chance to reform and adapt the positivist paradigm so that it is applicable to today's realities, while postmodernists firmly reject positivist assumptions and do not believe in the effectiveness of modernist reforms.

It will not be wrong to say at this point that the decline of the positivist conception of law was caused by social changes, and these should include above all:

1) the transformation of ethnically, culturally, religiously, and nationally homogeneous societies into multicultural societies that are highly diverse in these categories;

2) diversity of beliefs, value systems, and cultural backgrounds within societies, which has resulted in the destruction of a unified way of interpreting reality and has nullified the possibility of translating a single morality, goals, and aspirations into an entire society;

3) the unpredictability of the consequences of decisions and the impossibility of assessing risks on an individual and global scale;

4) the transition from an industrial society to a post-industrial society, which involves, among other things, greater mobility of individuals in social structures, and exacerbates globalization processes;

5) development of the information society, with easy access to information;

6) the development of attitudes that deny authority and the loss of faith in the power of law and justice;

7) the increasing complexity of societies and the processes within societies;

8) a loss of faith in the ideas and slogans that not long ago were held; a collapse of faith in the vision of achieving wealth, peace, stability, social position, progress [Sulikowski, 2015: 95-96].

Taking all the elements mentioned above into account, it would be worthwhile to refer to the statements of Grażyna Skąpska, who effectively describes postmodern society, whose features were practically indicated above, as changes that led to the overthrow of the positivist paradigm: "postmodern society is a globalizing polycentric society, without hierarchy, in which the traditional sovereignty of the state is being questioned and the boundaries between states are becoming increasingly fluid. It is a postcolonial and post-hegemonic society $[\ldots]$, a society in which large multinational corporations and civil society organizations are gaining importance $[\ldots]$, a society that is characterized by growing uncertainty and risk, and an expanding area of indeterminacy [...], 
a society that - due to the multiplicity, fluidity, fragmentation and alienation of law - must cope on its own" [Skąpska, 2008: 55-56].

Morawski also mentions, that "the crisis of the positivistic model of law was finally contributed to by the crisis of great ideologies, which tried to realize their ideals and programs by drawing on the positivistic concept of law [...]. The defeat of communism, the inefficiency of the welfare state programs and the extremely liberal model of economy, are also in a specific relation with the crisis of the positivistic ideology and the search for a new vision of law" [Morawski, 1999: 34].

Thus, it can be assumed that the end of the classical paradigms of law is de facto a refinement and completion of Max Weber's thesis on the "disenchantment of the world".

According to Jean-François Lyotard, the gap left by Weber's "disenchantment of the world", as well as the one that appeared as a result of the collapse of the great and traditional paradigms, was filled by the assumptions of Wittgenstein and Austin, thus restoring the power of metanarrative, based on the construction of the performative function of cultural and philosophical texts. Moreover, Luhman's theory of social systems proved helpful, where the scholar explicitly states that it is performativity that sustains the existence of the social system after the era of "disenchantment of the world", which disenchantment was caused by science and technology. According to Zirk-Sadowski, modernity's doing without the myth of the beginning as the ultimate justification of social systems and the discovery of performativity led Luhman to formulate the well-known thesis of the so-called autopoietic character of social systems. Autopoieticity, that is the self-reproduction and self-control of social systems, and within them legal systems as sets of meanings and symbols that form social relations, is made possible by the performative function of speech, which replaces in them the reality of physical systems" [Zirk-Sadowski, 2000: 141]. Systems theory assumes that it is possible to represent the social world and all knowledge in the form of meaning, symbolicity. Thus, the concept of performativity was considered in the autopoietic theory of law as another meta-arrative.

As Grażyna Skąpska notes: "Niklas Luhman's theory of social systems allows for the adoption of new optics in the analysis of society and the relation between society and law [...]. The conception of a social system and all the partial systems that make up society as communicative systems, self-creating and reproducing from their own elements, determined the formation of a new paradigm in social sciences, first of all in the sociology of law" [Skąpska, 2008: 55-72]. It is worth 
adding here that it is emphasized that the idea of fragmentation, multiplicity and mutually exclusive narratives is characteristic and crucial for postmodernism.

Michał Walczak, in an attempt to describe the current situation in relation to the dominance of the law paradigm, states that "it cannot be said at present that there is one dominant paradigm in legal science. Rather, we are dealing with many views, currents and theories that compete or complement each other in order to explain the complex nature of law" [Walczak, 2015: 79]. On the other hand, Skąpska makes the following analysis of the state of law in the contemporary world, citing that "the theory of law in postmodern society can be described as poststructuralist. It is based on the observation that the problem of law in the modern world is the modern world itself, i.e. the processes of the disappearance of social hierarchies, fragmentation and the growth of pluralism, the growing areas of ambiguity and risk, as well as globalization combined with quite radical changes in the internal sovereignty of the state" [Skąpska, 2008: 65-66].

\section{The end of grand narratives}

In science, we encounter the main narrative threads that are characteristic of a particular field. Narrative influences affecting science "from the outside", on the other hand, take the form of metanarratives, whose task is to "provide science or society as a whole with a credible goal of action" [Zirk-Sadowski, 2000: 140]. However, after Max Weber's formulation of the idea of "disenchantment of the world", i.e. the abandonment of social myths and traditions in order to explain reality with the help of Enlightenment technical reason, the question arises about the justification and maintenance of the credibility of metanarratives.

Paweł Skuczyński points to the theory of metanarration, "according to which modernity is characterized by the existence of theories that not only claim universal truthfulness, but also claim to explain the whole of reality and the rules that govern it, including providing criteria that determine the truthfulness of other theories" [Skuczyński, 2014: 143]. Postmodern societies, however, are strongly distrustful of any grand narratives that they believe have lost their credibility. How can a single narrative claim to be an all-theory of everything, able to contain such a changeable and violent world, in which, as Friedrich Nietzsche used to say - "Gott ist tot" - the whole basis of making sense of anything has collapsed, due to the unreliability of all previous matrices of understanding and explaining of all meaning. 
Based on the observation of the lack of faith in any attempts to explain and organise reality, Jean-François Lyotard developed a thesis according to which we are dealing nowadays with the collapse of metanarratives, which have gradually lost their legitimacy. In The Postmodern Condition the thinker writes as follows: "in contemporary society and in contemporary culture, in post-industrial society, in post-modern culture, the question of legitimacy takes on a different form. The great story, regardless of the way it unifies knowledge, that is, whether it is a speculative story or an emancipatory story, has lost its credibility" [Lyotard, 1997: 25-35].

Lyotard finds the cause of the decline of the story in the development of techniques and technologies, the renewal of liberal, developed capitalism, which at the same time contributed to the flowering of knowledge. According to him, "the crisis of scientific knowledge, signs of which have multiplied since the end of the nineteenth century, is not due to the accidental proliferation of science within the framework of technical progress and the expansion of capitalism. It results from an internal erosion of the principle of legitimacy of science" [Lyotard, 1997: 25-35].

As Wojciech Klimczyk notes: "the problem of metanarration is a problem of legitimation [...]. Metanarrations legitimize a number of more specific narratives, such as national histories, situating them within a discursive universe based on such pillars as freedom, the subject, humanity, human rights, or development" [Klimczyk, 2013: 54]. How, then, can they fulfil their function in societies where these very foundations are failing - in multicultural societies, where doubt is cast on the causal power of further human progress, where the idea of freedom is being redefined.

Michał Wróblewski, on the other hand, notes that Lyotard, in The Postmodern Condition, while considering the process of the delegitimization of knowledge and the fall of great metanarratives, "sees its source in the very logic of modernity, and thus admits that the final point, called postmodernism, was reached during the long journey that started in modernity" [Wróblewski, 2010: 134]. Klimczyk points out at this point that "myth is not subject to the rules of observation and proof, so it must be uprooted. Modernity thus disqualifies narrative as a form of knowledge. But only seemingly. The Enlightenment, having dealt with the divine guarantor of truth, tries to replace it with reason [...]. By removing myth, the Enlightenment removes the guarantee of unity" [Klimczyk, 2013: 53].

Thus, one can repeat after Klimczyk that "the basic tissue has dissolved" [Klimczyk, 2013: 65]. The order is nolonger legitimized by the common belief in 
"the sanctity of the traditions that have always beenin force and the legitimacy of the people who have been endowed with authority by those traditions" [Weber, 2002: 160]. As a result, "there are no longer fearsome gods, nor a universal, absolute God to whom one can appeal. The mystery of being thus loses its representation. Man thrown into thepost-metaphysical world has to be content with floating on the surface of things. There is onlythe surface [...]" [Klimczyk, 2013: 65].

At this point we should quote Marek Zirk-Sadowski, according to whom postmodernism "allows for the cooperation of mystical and rational cognition, it does not reject the usefulness of common experience and common sense in ordinary life. It is about finally transcending the myth of objectivity, separating the subject and the object of cognition, and replacing it with a multitude of stories, which is done by the mind in the field of art, science, philosophy, and everyday life [...]. Postmodernism does not mean rejecting the need for reflection, philosophy and thinking. It is merely skeptical, it rejects the domination of a single type of thinking, of mindfulness, of reflection, in which one presupposes something and then throughout the whole course of thinking and reflection implicitly defends it [...] [Postmodernism] is mainly a critical warning against dogma". What is more, Lyotard, unlike Max Weber, does not attribute a negative meaning to irrational factors. According to Skąpska, the scholar "emphasizes the positive effect of irrationality for questioning the aforementioned grand narratives justifying unity, coherence, systemicity" [Skąpska, 2008: 65].

In sum, the demise is a foregone conclusion for traditional paradigms and narratives relating to law. Social structures and the modern world have evolved to such an extent that the foundations on which the old schemes were based must necessarily fall into disuse. Nevertheless, bearing in mind the previous considerations about the transformation of old beliefs into new ideas, it is possible, and even certain, that we will encounter echoes of old traditions in new ways of explaining the validity of law. Today's world of declining old narratives will eventually be reshuffled, resulting in new structures that provide a new basis for legitimacy. New narratives will take the place of old ones; for the absence of "new myths" will lead to a chaos of cognition.

\section{Conclusions}

Today's changing world is faced with many problems that are completely new to humanity as a whole. For the first time in history we are faced with such dynamic 
changes that require us to redefine all cognition. We are scrupulously rejecting everything "old" and traditional, above all because of features that are completely unsuited to today's realities. This process leaves many societies with a sense of emptiness, marasmus, and even nihilism. The rejection of the old foundations, and the lack of yet created substitutes, about which it is doubtful that they will appear at all (or whether they will appear in a form that can answer the questions posed by the "post-world"), causes all the foundations of meaning to collapse. Repeating Lyotard, one can quote his statement that "most people have already lost even the longing for a lost story" [Lyotard, 1997: 25-35].

And yet, in his work Wojciech Klimczyk also quotes Lyotard, who wonders whether narration is perhaps a universal human need [Klimczyk, 2013: 52]. This would be evidenced by the discourses that are still being conducted by scholars, aimed at identifying new structures for the "new myths" that meet these needs. Michał Wróblewski rightly observes that "we cannot fully disregard the metaphysical heritage, but, aware of its contingency and fluidity, we must learn to live with it. For one cannot conduct philosophical reflection without metaphysics" [Wróblewski, 2012: 131]. Even because of this, it should be said that we are not completely breaking with the narrative character of knowledge, but we are transforming the character of narration" [Klimczyk, 2013: 52].

I have previously compared the collapse of old paradigms of law and narrative to the concept of the Big Collapse. But perhaps there is a pulsation of sorts, and after the collapse, there will be a new Big Bang that will allow us to create a framework that fits into and keeps up with today's dynamic world.

\section{| References}

Cuprjak M., 2016, Paradygmaty w perspektywie zmian społecznych. Zarys problemu, "Rocznik Andragogiczny", No. 23, pp. 251-265.

Kępa M., 2015, Metodologiczne ujęcie paradygmatu jako metody badawczej na przykładzie koncepcji Thomasa Kuhna, [in:] P. Fiktus, H. Malewski, M. Marszał (eds.), Rodzinna Europa. Europejska myśl politycznoprawna u progu XXI wieku, Wrocław, pp. 361-370.

Khun T., 2001, Struktura rewolucji naukowych, Warszawa.

Klimczyk W., 2013, Metanarracja mobilizacji. Ponowoczesność jako bezruch?, "Diametros", No. 37, pp. 51-68.

Lyotard J.-S., 1997, Kondycja ponowoczesna (fragmenty), "Sztuka i Filozofia”, No. 13, pp. 25-35. 
Morawski L., 1999, Główne problem współczesnej filozofii prawa, Warszawa 1999, pp. 15-35.

Skąpska G., 2008, Prawo w ponowoczesnym społeczeństwie, "Zarządzanie Publiczne”, No. 4 (6), pp. 55-72.

Skuczyński P., 2014, Typy myśli krytycznej w prawoznawstwie. Od krytyki poznania do walki o uznanie, [in:] M. Zirk-Sadowski, B. Wojciechowski, T. Bekrycht (eds.), Integracja zewnętrzna i wewnętrzna nauk prawnych, Vol. 1, Łódź, pp. 133-148.

Sulikowski A., 2015, Prawo po śmierci Boga. Prawoznawstwo a niektóre konstatacje wspótczesnej filozofii, "Principia”, No. 61-62, pp. 89-106.

Walczak M., 2015, Teoria paradygmatu i jej zastosowanie $w$ naukach prawnych, "Zeszyty Naukowe Towarzystwa Doktorantów UJ", No. 10, pp. 67-80.

Weber M., 2002, Gospodarka i społeczeństwo. Zarys socjologii rozumiejaccej, Warszawa [selected fragments].

Wróblewski M., 2010, Zatarg Jeana-Françoisa Lyotarda, czyli o postmodernizmie raz jeszcze, "Diametros", No. 24, pp. 125-142.

Zirk-Sadowski M., 2000, Wprowadzenie do filozofii prawa, Kraków, pp. 132-141. 